\title{
CELL WALL COMPOSITION OF CHLOROCOCCAL ALGAE
}

\author{
Maria Blumreisinger, Doris Meindl and ECKhard LoOS \\ Institut für Botanik. Lniversität Regensburg, Universitätsstraße 31, D-8400 Regensburg, West Germany
}

(Revised receited 30 Notember 1982)

Key Word Index Chlorococcal algae; cell wall composition.

\begin{abstract}
The cell walls of representatives of the genera Chlorella, Monoraphidium, Ankistrodesmus and Scenedesmus contained $24-74 \%$ neutral sugars, $1-24 \%$ uronic acids, $2-16 \%$ protein and $0-15 \%$ glucosamine. Two types of cell walls could be discerned containing as main sugars either rhamnose and galactose or mannose and glucose with a lack of galactose.
\end{abstract}

\section{INTRODUCTION}

There are differing reports on the cell wall composition of chlorococcal algae: walls rich in galactose, glucose and rhamnose have been described $[1,2]$, walls with mannose and glucose as main constituents [3-5] and walls with a significant amount of glucosamine [6]. To establis:: whether these are types of more common occurrence, analyses were made from walls of eight representatives of the chlorococcal algae.

\section{RESULTS AND DISCUSSION}

A major component of all cell walls examined were neutral sugars (Table 1); the content of uronic acids and protein was less and varied considerably from species to species. In two cases, significant amounts of glucosamine were encountered. Unknown material was calculated to represent up to $50 \%$ of the cell walls' dry wt. The data in Table 1 give only an approximation to the real composition of the cell walls since, e.g. losses of neutral sugars and amino sugars could have occurred during hydrolysis.

In the pattern of neutral sugárs, two types could be discerned: one with rhamnose and galactose as prominent components (rhamnose/galactose type), and another with mannose and glucose as main sugars and an essential lack of arabinose and galactose (mannose/glucose type; Table 2). This type is realized also in $C$. fusca $211-8 \mathrm{~b}$ [5] and most probably also in Hydrodictyon [3] and Pediastrum [4]. To the rhamnose/galactose type obviously belong the strains of C. pyrenoidosa used by Northcote et al. [1] and by Becker and Shefner [2]. Interestingly, it seems to be restricted to the genus Chlorella, whereas the mannose/glucose cell wall type occurs in several genera.

$C$. fusca, $M$. braunii and $S$. obliquus have been shown to be capable of photoreduction and formation of secondary carotenoids, whereas $C$. vulgaris and $C$. saccharophila are lacking these properties [7]. Since this correlates with the two types of cell walls, the grouping of the algae in Table 2 probably reflects a natural relationship within each group.

Some heterogeneity, however, exists in the group belonging to the rhamnose/galactose type: $C$. saccharophila was distinguished by a relatively high glucose content of the cell wall and $C$. vulgaris $\mathbf{K}$ by an appreciable amount of an unknown sugar (Table 2). The two strains of $C$. vulgaris with glucosamine in the cell wall may be related to C. ellipsoidea, which contains a considerable amount of glucosamine in the structural polysaccharide [6].

\section{EXPERIMENTAL}

The following algae were obtained from Sammlung für Algenkulturen, Göttingen, West Germany: Chlorella vulgaris strain 211-81 and 211-11f, Chlorella saccharophila strain 211-1a, Chlorella fusca strain 211-8c, Monoraphidium braunii strain 202$7 \mathrm{~b}$, Ankistrodesmus densus strain 202-1 and Scenedesmus obliquus strain 276-3a. Chlorella vulgaris strain K was kindly supplied by N. Sauer in our Institute.

The algae were grown in continuous light $(6 \mathrm{klx})$ and harvested

Table 1. Cell wall composition $(\%$ dry wt) of members of chlorococcal algae

\begin{tabular}{lccccc}
\hline Alga & $\begin{array}{c}\text { Neutral } \\
\text { sugars }\end{array}$ & $\begin{array}{c}\text { Uronic } \\
\text { acids }\end{array}$ & Glucosamine & Protein & Unknown \\
\hline C. culgaris K & 74 & 4.1 & & 3.9 & 18 \\
C. culgaris 211-81 & 24 & 18 & 6.3 & 4.5 & 47 \\
C. culgaris 211-11f & 44 & 24 & 15 & 3.9 & 13 \\
C. saccharophila 211-1a & 54 & 14 & 0 & 1.7 & 30 \\
C. fusca 211-8c & 68 & 6.9 & 0 & 11 & 14 \\
M. braunii 202-7b & 47 & 6.1 & 0.4 & 16 & 31 \\
A. densus 202-1 & 32 & 2.3 & & 14 & 52 \\
S. obliquus 276-3a & 39 & 1.2 & 0 & 15 & 45 \\
\hline
\end{tabular}


Table 2. Distribution of neutral sugars $(\%$ by wt of total $)$ in cell walls of members of the chlorococcal algae

\begin{tabular}{lccccccccc}
\hline Alga & Rha & Fuc & $\mathrm{X}_{1}$ & Ara & $\mathrm{Xyl}$ & $\mathrm{X}_{2}$ & Man & Gal & Gilc \\
\hline C. tulgaris K & 47 & 0 & 13 & 1.6 & 7.1 & 0 & 1.7 & 26 & 3.6 \\
C. tulgaris 211-81 & 45 & 0 & $<1$ & 9.0 & 19 & 0 & 6.7 & 18 & 1.7 \\
C. tulgaris 211-11f & 54 & $<1$ & $<1$ & 6.6 & 10 & 8.8 & 5.4 & 14 & $<1$ \\
C. saccharophila 211-1a & 26 & 0 & 1.2 & 2.2 & 3.3 & 0 & 18 & 27 & 22 \\
C. fusca 211-8c & 2.4 & $<1$ & $<1$ & $<1$ & $<1$ & 0 & 66 & 0 & 30 \\
M. braunii 202-7b & 4.2 & $<1$ & 0 & 0 & 1.7 & 0 & 72 & 0 & 22 \\
A. densus 202-1 & 1.7 & 0 & 0 & 0 & $<1$ & 0 & 79 & 0 & 19 \\
S. obliquus 276-3a & $<1$ & 1.6 & 0 & 0 & 0 & 0 & 25 & 0 & 73 \\
\hline
\end{tabular}

The sugars are ordered after the retention time of their alditol acetates in GC. Rha, Rhamnose; Fuc, fucose; Ara, arabinose: $X y l$, xylose: Man, mannose; Gal, galactose; Glc, glucose: $X_{1}$ and $X_{2}$, unknowns.

2-3 days after inoculation; other conditions of culture were as described in ref. [5]. Cell walls were isolated as in ref. [5]; in the case of $S$. obliquus, however, the cells had to be broken by a glass bead homogenizer, since they resisted the usual French press treatment. Neutral sugars were obtained after hydrolysis in $\mathrm{H}_{2} \mathrm{SO}_{4}$ according to ref. [8]. They were determined as the respective alditol acetates by GC with FID using a column $(1.8 \mathrm{~m}$ $\times 2 \mathrm{~mm})$ with $3{ }_{0}$ SP- $2340, \mathrm{~N}_{2}$ as carrier gas $(28 \mathrm{ml} / \mathrm{min})$, and a temp. program of $190-225$ at 2 min. Aminosugars released after $18 \mathrm{hr}$ in $6 \mathrm{M} \mathrm{HCl}$ at $105^{\circ}$ were determined similarly, however, with isothermal operation $\left(240^{\circ}\right)$. Inositol was used as int. standard throughout. Uronic acids in the cell walls were determined after ref. [9] and protein after ref. [10] with galacturonic acid and bovine serum albumin as standards. respectively. The values for uronic acids were corrected to account for colour formation due to neutral sugars.

Acknowledgement - This work was supported by the Deutsche Forschungsgemeinschaft.

\section{REFERENCES}

1. Northcote, D. H.. Goulding, K. J. and Horne, R. W. (1958) Biochem. J. 70, 391.

2. Becker, M. J. and Shefner, A. M. (1964) Nature (London) 202, 803.

3. Northcote, D. H., Goulding, K. J. and Horne, R. W. (1960) Biochem. J. 77, 503.

4. Parker, B. C. (1964) Phycologia 4, 63.

5. Loos, E. and Meindl, D. (1982) Planta 156, 270.

6. Takeda, H. and Hirokawa, T. (1978) Plant Cell Physiol. 19, 591.

7. Kessler, E. (1962) in Beiträge zur Physiologie und Morphologie der Algen (Deutsche Botanische Gesellschaft, ed.) p. 92. Fischer, Stuttgart.

8. Saeman, J. F., Buhl, J. L. and Harris, E. F. (1945) Ind. Eng. Chem. Anal. Ed. 17, 35.

9. Galambos, J. T. (1967) Analyt. Biochem. 19, 119.

10. Lowry, O. H., Rosebrough, N. J., Farr, A. L. and Randall, R. J. (1951) J. Biol. Chem. 193, 265. 